\section{Betrayal of Trust: The Collapse of Global Public Health}

Laurie Garret is a journalist who has written extensively on health. The central argument of her book is that public health is a "public good", providing communitylevel protection from infectious diseases and environmental hazards, and access to medical for the poor. These benefits to the collective are the responsibility of national governments and international agencies such as World Health Organization. The "betrayal of trust" in thetitle of the book refersto the failure to meet these responsibilities, which, in Garret's view, has led to a collapse of global public health. To illustrate her argument, she cites examples of the inadequacies of epidemic control in developing countries, the disintegration of public health in the former Soviet Union, and the deterioration of public health infrastructure in the United States.

Garret describes a 1994 epidemic of pneumonic plague in Surat, India that was mismanaged and led to panic, mass migration and spread of infection. She then describes the 1995 outbreak of Ebola in Kikwit, Zaire, which resulted in approximately 500 cases of disease, many among health personnel who treated highly infectious patients without protection. The inadequate response to the Ebola epidemic was, in large part, due to the absence of infrastructure under the corrupt Mobutu regime. Unfortunately, these accounts fail to separate substance from sensationalism. Garrett's bleak picture is in contrast to Ugandan management of a re cent Ebola outbreak in Gulu, in which health authorities quarantined the area, provided protection for health personnel, welcomed international assistance, and mounted a public information campaign to detect new cases and to control panic.
Thus, Garret's examples of the responses of the Indian and Zairian authorities illustrates what can go wrong rather than what can be done right, even in resource poor settings. Moreover, her emphasis on emotive epidemics ignores the steady improvements in child survival in developing countries over the past 25 years, which was achieved by immunization campaigns and improved primary care.

Garrett documents the collapse of public health in the former Soviet Union, which has experienced resurgent diphtheria, emergence of multi-drug resistant tuberculosis and explosive epidemics of HIV and hepatitis due to intravenous drug addiction. The old Soviet system used punitive, authoritarian and anachronistic approaches to disease control. Infant and adult mortality increased under the communist administration, and the fall of communism led to an implosion of an already anarchic system, resulting in further reductions of adult life expectancy. The current economic crisis and chaos in Russia offer little hope of reform, and disease problems in Russia pose a threat to the rest of Europe.

Garrett provides a history of public health in the US and documents contributions to improved life expectancy during the first half of the $20^{\text {th }}$ century. She then relates the decline of the public health and medical care infrastructure during the past 30 years which has left more than 40 million people without medical insurance, a disturbing deterioration of public medical care services for the poor, and a national decline in immunization coverage among children. She chronicles the impact of the Reagan and Bush administrations and the failed medical care reforms of the Clinton era, arguing that public health philosophy has shifted from protection of the collective to a new paradigm in which health promotion and disease prevention are now individual responsibilities. Health authorities in the US have repeatedly set health targets in reports such as Healthy People 1990 and 2000 (from the Office of Disease Prevention and Health Promotion), without defining the strategies needed to achieve the laudatory goals, and the debate has been how to pay for medical care rather than how to promote health.

Garrett rightly emphasizes new threats to the public's health as a consequence of globalization, whereby air travel and the importation of food from developing countries facilitate dissemination of infectious diseases. Emerging infections such as HIV, the spread of antibiotic resistant bacteria and food born epidemics, and the threats of biologic warfare and bioterrorism, constitute international challenges at a time when the infrastructure for disease surveillance and control is being eroded.

This is an important book that cogently argues that public health is critical to the welfare of global society and it is a major concern that services have deteriorated worldwide. Sadly, however, this lengthy tome (585 pages with 153 pages of notes), is often poorly or hastily written and badly in need of editorial discipline. Ms. Garrett is clearly knowledgeable, but she presents a flurry of statistical and anecdotal "factoids", which overwhelm the thrust of her arguments, and many notes refer to her previous writings rather than primary or authoritative sources. There are, unfortunately, many errors of fact and a troubling lack of judgment in use of statistical data. These errors and the propensity to sensationalize serious problems undermine the credibility of the book, and I cannot recommend this lengthy volume to either an expert or lay audience.

The Eradication of Smallpox: Edward Jenner and The First and Only Eradication of a Human Infectious Disease

\author{
by Herve Bazin \\ Academic Press, 246 pp, $\$ 49.95$ \\ ISBN 0120834758, 2000
}

Reviewed by Kevin M. De Cock

Centers for Disease Control and Prevention Nairobi, Kenya

I picked this book up with eager anticipation and put it down with a mixture of admiration and disappointment. Written by a French-speaking immunologist and translated into English, the book deals less with the eradication of smallpox than Jenner's contributions to the development of vaccination and the early history of this public health strategy. The eradication of smallpox, undoubtedly one of public health's greatest achievements, could not have 